\author{
Anna Maria TOMCZAK \\ Uniwersytet w Białymstoku \\ atomczak@uwb.edu.pl \\ Małgorzata JANICKA-BIERYŁO \\ Uniwersytet w Białymstoku \\ jacinta@poczta.neostrada.pl
}

\title{
JĘZYK HISZPAŃSKI JAKO ELEMENT NARRACJI W POWIEŚCI MARLONA JAMESA KRÓTKA HISTORIA SIEDMIU ZABÓJSTW
}

Powieść Marlona Jamesa Krótka historia siedmiu zabójstw to utwór polifoniczny w podwójnym znaczeniu. Odnajdziemy w nim wielogłosowość (heteroglossię) w rozumieniu Bachtinowskim, dzięki której postaci świata przedstawionego mogą być odczytane jako bohaterowie wchodzący w relacje tworzące "nieskończony dialog wokół spraw ostatecznych" (Bachtin 1986: 502), wynikający z różnorodnych punktów widzenia, światopoglądów i ideologii, co może skutkować wielością interpretacji (Cobley 2014: 95). Równocześnie wielogłosowość (polifonia) utworu występuje także $w$ znaczeniu dosłownym, gdyż język narracji (w oryginale) stanowi połączenie angielskiego i jamajskiego, z wplecionymi elementami zaczerpniętymi z hiszpańskiego, zaś w polskim tłumaczeniu zachowuje obcojęzyczne wtrącenia ${ }^{1}$. Niniejszy artykuł jest próbą określenia roli, jaką pełnią wtręty z języka hiszpańskiego w tekście adresowanym, jak się wydaje, do czytelnika jednojęzycznego. Zasadniczą dyskusję poprzedzi część informacyjna, zarysowująca konstrukcję utworu, przebieg akcji, sylwetki bohaterów i kontekst społeczno-polityczny przedstawionych wydarzeń.

Krótka historia siedmiu zabójstw wcale nie jest krótka, a liczby postaci, które tracą $\mathrm{w}$ niej życie nie sposób określić nawet w przybliżeniu. Na blisko ośmiuset stronach swojej najnowszej (i trzeciej z kolei) powieści,

1 Takie dosłowne rozumienie polifonii przyjęte jest $\mathrm{w}$ translatoryce, $\mathrm{np}$. Hejwowski 2010: 41. 
Marlon James kreśli obraz Jamajki drugiej połowy lat siedemdziesiątych XX wieku oraz Miami i Nowego Jorku na przełomie dekady lat 1980-90. Wątkiem łączącym te lokalizacje jest handel narkotykowy i działalność gangów. Tytuł książki nawiązuje do planowanej serii artykułów, w których dziennikarz amerykański (jeden z bohaterów Krótkiej historii) opisuje tragedię w nowojorskiej melinie narkotykowej, kiedy to zaledwie w ciągu kilku chwil siedem osób traci życie i stąd właśnie pojawiająca się w tytule magiczna liczba siedem, której znaczenie czytelnik odkrywa dopiero pod koniec lektury. Zabójcą jest Josey Wales, don potężnego gangu działającego na terenie Kingston, Miami i Nowego Jorku, pierwszoplanowy anty-bohater utworu. Zarówno opisane wydarzenie, jak i osoba psychopatycznego mordercy, umocowane są $\mathrm{w}$ faktach historycznych, podobnie jak wiele innych sytuacji i wątków powieści Jamesa. Jednym z takich autentycznych wydarzeń a zarazem elementem kluczowym fabuły jest nieudany zamach na życie Boba Marleya przeprowadzony w stolicy Jamajki w grudniu 1976 roku, za wiedzą i zgodą CIA. Tłem akcji jest brudna polityka: podział terytorium kontrolowanego przez grupy przestępcze, kupowanie głosów jamajskiej biedoty, biznes narkotykowy, machinacje CIA potajemnie uzbrajającej karaibskich gangsterów w imię walki z komunizmem, beznadzieja i brak perspektyw wyznaczające trajektorię losów licznych mieszkańców wielkomiejskich gett.

Krótka historię siedmiu zabójstw przepełnia przemoc. To książka obfitująca w drastyczne sceny okrucieństwa, w której zabójcami stają się kilkunastoletnie dzieci ze slumsów Kingston; powieść ukazująca brutalność policji i zakulisowe niecne knowania skorumpowanych polityków, bezpardonową walkę o władzę gangsterów i baronów narkotykowych oraz bezprawne poczynania cynicznych agentów amerykańskich. Ale to także utwór niezwykły i fascynujący, złożony z kilkudziesięciu narracji $\mathrm{w}$ pierwszej osobie tworzących polifoniczny wielogłos odsłaniający realia życia tropikalnej wyspy Trzeciego Świata i mentalność jej mieszkańców. W ten kulturowy pejzaż i jego muzyczną symfonię ściśle wpisane są wierzenia i tradycje afrykańskich przodków i przekaz słowny. Jamajskie brzmienie utworu to nie tylko reggae i dźwięki globalnej popkultury, to także melodyjna różnorodność języka bohaterów świata przedstawionego. Każdy z kilkunastu narratorów posługuje się tu bowiem sobie właściwą charakterystyczną wersją angielszczyzny lub jamajskiego patois, od eleganckiej prozy z czasów zdobyczy imperialnych, gdy Jamajka znajdowała się pod panowaniem Brytyjczyków, poprzez mowę potoczną 
rodem z amerykańskiej ulicy lat siedemdziesiątych, po specyficzne odmiany kreolskiego. Warstwa słowna powieści stanowi momentami duże wyzwanie dla czytelnika, zasugerowane już na wstępie w przysłowiu zamieszczonym jako motto: "If it no go so, it go near so" (James 2015: xv), co można przetłumaczyć jako: „jeśli to nie było dokładnie tak, to było to prawie tak", czego polska wersja zaproponowana przez tłumacza jako: "Jak się całkiem nie da, to nie całkiem da się" (James 2016: 11) nie oddaje $\mathrm{w}$ pełni. To krótkie zacytowane powyżej zdanie przynosi pewien przekaz, zwracając uwagę odbiorcy na kilka ważnych kwestii. Po pierwsze, sugeruje autentyczność opowieści, umocowanie przedstawionej historii w faktach rzeczywistych. Po drugie, nawiązuje do mocno zakorzenionej w kulturze Karaibów tradycji kultury słowa mówionego raczej niż pisanego, z jej nieodzownym składnikiem folkloru i mądrości ludowej utrwalanej przez pokolenia, mądrości obfitującej w przysłowia, przypowieści, aforyzmy i zagadki. Po trzecie, poprzez swoje poetyckie brzmienie, nagromadzenie wyrazów jednosylabowych i powtórzenia, akcentuje doniosłą rolę języka potocznego w konstruowaniu narracji. To właśnie język bohaterów stanowi o sile twórczości Jamesa. Książka zdobyła w 2015 r. nagrodę Bookera, najbardziej prestiżowe wyróżnienie dla powieści anglojęzycznej, a jak donosiła prasa (na przykład Tayler 2015), jurorzy byli tym razem jednomyślni. W Polsce ukazała się w roku 2016, w tłumaczeniu Roberta Sudoła, nakładem Wydawnictwa Literackiego.

Rytm i melodia jamajskiego języka ulicy i frazeologia rodem z rynsztoka, rastafariańskie wariacje na temat przedimków i zaimków, czy żargon amerykańskich gangsterów stanowią istotny składnik artystycznego wymiaru utworu. Wśród kilkudziesięciu monologów wewnętrznych tworzących narrację odnajdziemy kakofoniczny strumień zaburzonej świadomości mordercy w narkotykowym ciągu, obok wyrafinowanej, pełnej głębokiej refleksji, wnikliwej obserwacji poczynionej przez ducha zamordowanego polityka. Wiele postaci demonstruje niemałą wirtuozerię w praktyce manipulowania kodem językowym. Żaden z narratorów nie brzmi tak samo. Każdy przedstawia swoją fragmentaryczną wersję zdarzeń, we właściwy sobie sposób, a czytelnik odkryje pełne znaczenie utworu dopiero wtedy, gdy zamilkną ostatnie dźwięki narracji. W tym mozaikowo odmiennym i porywającym wielogłosie, od czasu do czasu, pobrzmiewa też język hiszpański i nie jest to partia solowa. Chociaż pozornie hiszpańskie wyrazy i zdania stanowią mikroskopijną część narracji, spełniają jednak istotną rolę zarówno w funkcji identyfikacji i uwiary- 
godnienia bohaterów jak też w konstruowaniu związków między nimi. Występują w formie oryginalnej, bez przypisów i wyjaśnień, przy zaznaczeniu ich obcości kursywą, zarówno w tekście pierwotnym, jak i w polskim tłumaczeniu. Z punktu widzenia postaci wplatających zwroty i poszczególne słowa hiszpańskie, możemy odnotować cztery zazębiające się obszary dyskursu:

1. Sporadyczne hiszpańskie wtrącenia w rozmowach amerykańskich agentów CIA przebywających na Jamajce;

2. Równie sporadyczne wtrącenia w dialogach zarówno jamajskich jak też amerykańskich gangsterów działających na terenie Florydy oraz Nowego Jorku;

3. Dłuższe konstrukcje i zdania w narracji Josey'ego Walesa, jednego z głównych bohaterów, wspomnianego wcześniej wykonawcy siedmiu tytułowych zabójstw;

4. Hiszpańskie odzywki Doktora Love - kubańskiego terrorysty, ważnej postaci, jedynej dla której hiszpański jest językiem ojczystym a angielski językiem obcym.

W przypadku dwóch pierwszych obszarów, rola hiszpańskiego wydaje się drugoplanowa, w przypadku dwóch ostatnich - znacznie istotniejsza.

\section{AGENCI CIA}

Wykorzystanie zwrotów hiszpańskich przez agentów Centralnej Agencji Wywiadowczej spełnia podwójną rolę. Po pierwsze akcentuje stałą obecność wywiadu amerykańskiego na terenie Ameryki Łacińskiej w latach siedemdziesiątych dwudziestego wieku, po drugie sugeruje podobną obecność na terenie hiszpańskojęzycznej Kuby, zwłaszcza w kontekście podejrzanej roli przypisywanej agentowi Adlerowi. Na przykład, pojawiający się w końcowej partii utworu pan Clark, nowy agent CIA obejmujący funkcję rezydenta na Jamajce po Barrym Diflorio, jako sposób przedstawienia się i zaakcentowania swojej zażyłości z kubańskim terrorystą dodaje: „Luis i ja znamy sie $^{2}$ jak łyse konie. Właściwie za długo nawet. Kilka estados latinos wcześniej, co?" (James 2016: 457). Czytelnicy zarówno polskiego tłumaczenia jak i angielskojęzycznego oryginału bez trudu domyślają się, że pan Clark informuje rozmówcę, że działał

2 Błędy gramatyczne, stylistyczne i ortograficzne występujące w polskich cytatach są sposobem przyjętym przez tłumacza na oddanie dialektu jamajskiego. 
wcześniej na terenie Ameryki Łacińskiej lub jakichś państw hiszpańskojęzycznych. Jeśli nawet hiszpańskie estados (kraje) pozostaje dla czytelnika słowem obcym, żadnych trudności nie sprawia zrozumienie słowa latinos, które jest powszechnie wykorzystywanym zapożyczeniem w języku angielskim. Podobnie zrozumiałe są dodane jeszcze "Exactamente" (James 2016: 457) oraz „Hasta la Vista!” (James 2016: 460). Pierwsze - poprzez swoje podobieństwo do angielskiego odpowiednika, drugie - dzięki rozpowszechnieniu poprzez turystykę i pop kulturę.

Innym przykładem może być rozmowa telefoniczna agenta Diflorio z Williamem Adlerem, kończąca się słowami: „Dobranoc, Bill. Albo hasta mañana, albo luego, albo cokolwiek" (James 2016: 116), która sugeruje, że Bill Adler jest na Kubie i być może współpracuje z Fidelem Castro. Co istotne, tych kilka wykorzystanych zwrotów, można uznać za język neutralny, nienacechowany kulturowo, bez wyraźnego rejestru społecznego, którego główną funkcją jest nie tyle charakterystyka postaci co sugerowanie rzeczywistych powiązań politycznych i akcentowanie rozległej działalności amerykańskiej Centralnej Agencji Wywiadowczej poza granicami USA.

\section{GANGSTERZY}

Drugim obszarem wykorzystania w narracji języka hiszpańskiego są pojedyncze słowa wplecione do dialogów amerykańskich i jamajskich gangsterów działających na terenie Nowego Jorku i Florydy, w tym osób odpowiedzialnych za kontakty z mafią kolumbijską. W przeciwieństwie do języka agentów CIA, obok krótkich, wnoszących niewiele treści wtrętów typu ranchero, chico, chica, guapo czy muchacho, dominują w nim wulgaryzmy. Jako przykład może służyć zdanie: „Fuck that little putito" (James 2015: 460), przetłumaczone na: "Jebać tego putito" (James 2016: 509), obok takich określeń jak: mariconcito, maricones, pendejo. Wymieszanie wulgaryzmów hiszpańskich i angielskich (np. fuck + puttito) spełnia kilka istotnych funkcji. Przede wszystkim jest sposobem na ukazanie powszechnej obecności hiszpańskojęzycznych przekleństw w amerykańskim Miami. Floryda, leżąca w bezpośrednim sąsiedztwie Kuby (ok. 145 km), jest stanem o największej liczbie Kubańczyków w USA, gdzie językiem hiszpańskim posługuje się około $20 \%$ populacji. Po drugie, wykorzystany rejestr językowy należy do tzw. języka ulicy i nizin, jest zatem społecznie nacechowany. Charakteryzuje kontakty 
jamajskich i amerykańskich gangsterów z przedstawicielami karteli narkotykowych Ameryki Południowej, co podkreśla związek między patologią, ubóstwem i kryminogennym brakiem perspektyw. Występujące przekleństwa stanowią rodzaj przerywników i znaczników dyskursu, które nie odzwierciedlają sytuacji stresu lub zagrożenia, co potęguje silnie zaakcentowaną w utworze zależność języka narracji od pozycji społecznej osobowy prowadzącej dialog.

W badaniach językoznawczych (np. Wierzbicka 1997) zazwyczaj uwypukla się związek między przeklinaniem i obecnością afektu. Ludzie klną, kiedy chcą dać upust silnym emocjom. Używanie słów niecenzuralnych jest też często sposobem zamanifestowania więzi łączącej rozmówców, zwłaszcza gdy dotyczy to grupy, której zażyłość cementują związki wynikające z przynależności do zamkniętego środowiska (Fägersten 2012: 13-15). Blake (2010: 211) podkreśla, że szczególną rolę czynnika spajającego grupę odgrywać może postawa aspołeczna i poczucie marginalizacji bądź aktywnego przyjęcia stanowiska kontestującego obowiązujące normy. Świadomość bycia poza prawem jest czynnikiem aktywizującym komunikację przy pomocy socjolektu, co przykłady rozmów gangsterów z Krótkiej historii wymownie ukazują. Ilustrują one także istniejące uwarunkowania w relacjach między językiem i władzą, unaoczniając tendencję do budowania pozycji w grupie poprzez asertywność słowną. Co więcej, tworząc specyficzną mowę gangsterów James posługuje się językiem, który jest jednocześnie lokalny i globalny - lokalny $\mathrm{w}$ swej funkcji charakteryzującej w miarę hermetyczną grupę działającą na ściśle określonym obszarze, a zarazem globalny poprzez wplecenie języka obcego i udokumentowanie doświadczania procesów globalizacyjnych na poziomie osobistym. Mowa gangsterów nie tylko odkrywa istnienie ścisłych powiązań lokalnych opartych na zamkniętych strukturach świata przestępczego i komunikacji wewnątrzgrupowej, jest też przykładem na to, że wspólne interesy i hierarchizacja odgrywanych ról mają bezpośredni związek z posługiwaniem się językiem.

\section{NARRACJA JOSEY'EGO WALESA}

Znacznie więcej przykładów wykorzystania języka hiszpańskiego znajdziemy $w$ dialogach $\mathrm{z}$ udziałem Josey'go Walesa. Tym razem zdania i zwroty hiszpańskie służą budowaniu konkretnej postaci. W przypadku 
Josey'go, znajomość hiszpańskiego odzwierciedla „postaciowanie pośrednie" (Markiewicz 1996: 169), pozwala bowiem na dopełnienie charakterystyki jednego z głównych bohaterów na podstawie innych informacji niż określenie płci, wieku, wyglądu, czy sytuacji społecznej. Stylistyczne ukształtowanie wypowiedzi Walesa, wzbogaconych o zdania i zwroty hiszpańskie, nie tyle służy potrzebie rozwijania fabuły, ile jest zabiegiem wzbogacającym funkcję interpretacyjną. Dzięki obco brzmiącym wtrąceniom $\mathrm{w}$ angielskiej narracji czytelnik dowiaduje się, że Josey znacznie różni się od pozostałych jamajskich gangsterów, góruje nad nimi inteligencją, płynnością i łatwością wypowiedzi, znajomością wyszukanych słów. Josey Wales chlubi się swoim talentem werbalnym, choć ukrywa przed innymi posiadaną umiejętność prowadzenia konwersacji $w$ języku obcym. Znajomość hiszpańskiego pozwala mu na bezpośrednie kontakty z mafią kolumbijską oraz na swobodną rozmowę z Kubańczykiem. Już w scenie pierwszego spotkania z Doktorem Love, czytamy: „Nie mówie mu yo tengo suficiente español para conocer que eres la más gran broma en Sudamérica" (James 2016: 59). Częste osobiste kontakty z wpływowymi przedstawicielami kartelu z Medellin i czołowa rola odgrywana w funkcjonowaniu syndykatów narkotykowych na Jamajce i w USA wymagają od Josey'go regularnych podróży na Wyspy Bahama i na Florydę, a jego funkcja dobrze ustosunkowanego dona sytuuje go wysoko w hierarchii przestępczej. $\mathrm{W}$ obu przypadkach, znajomość hiszpańskiego ma znaczenie kluczowe. Co więcej, choć w wypowiedziach Josey'go pełnych zdań w języku hiszpańskim jest zaledwie kilka, tzw. „native speaker" jest $\mathrm{w}$ stanie rozpoznać złożenia frazowe charakterystyczne dla cudzoziemców. Profesor Jose Maria Perez Fernandez z Uniwesrytetu w Granadzie uważa ${ }^{3}$, że zdanie "yo tengo suficiente español para conocer que eres la más gran broma en Sudamérica" (James 2016: 59) nie brzmi jak wypowiedź rodowitego Hiszpana, gdyż wyrażenie la más gran broma en Sudamérica jest anglicyzmem. Jak wskazują badania socjolingwistyczne, cechy dystynktywne wariantów mowy wykorzystywanych przez poszczególnych członków jakiejś wspólnoty językowej zmieniają się w zależności od sytuacji, w której znajduje się rozmówca. W przypadku Josey'ego wykorzystanie hiszpańskiego dotyczy wyłącznie kontaktów z Kubańczykiem.

\footnotetext{
3 Jose Maria Perez Fernandez, Professor Titular de Literatura Inglesa: opinia wyrażona w prywatnej korespondencji elektronicznej z dnia 27 marca 2016. Zgoda na wykorzystanie listu wyrażona w korespondencji z dnia 25 kwietnia 2017.
} 
Dialogi Walesa i Doktora Love stanowią rodzaj kodu, którym rozmówcy posługują się jedynie we wzajemnych relacjach. Jednocześnie jednak język Walesa jako monolog udialogizowany, w którym wyraźnie zaznaczono zmieniające się rejestry, uwypukla związek tekstu z jego wysoce heterogenicznym kontekstem społeczno-kulturowym. Wyspy Karaibskie, w tym Jamajka, stanowią mozaikę kulturowo-językową o dużym bogactwie wpływów i przenikających się obszarów odmienności.

\section{DOKTOR LOVE}

Doktor Love naprawdę nazywa się Luis Hernán Rodrigo de la Casas i jest kubańskim terrorystą działającym na terenie wielu krajów Ameryki Łacińskiej. Na Jamajce angażuje się w handel bronią oraz przeróżne akcje terrorystyczne eskalujące wojnę gangów. Często przeplata swoje wypowiedzi wtrętami z hiszpańskiego. Np.:

"lekarze też odbierają życie, hombre." (James 2016: 188)

"Amigo, słówko do ciebie." (James 2016: 191)

"kontrrewolucja to akt miłości, hermano, a nie wojny." (James

2016: 188)

„Rany, muchacho, nie chciałem nikogo obrazić." (James 2016: 189)

"a już mnie łączysz z americano." (James 2016: 189)

„Do szkoły chodziłem w Oslo, muchacho." (James 2016: 189)

Kiedy Josey Wales reaguje na „muchacho”, zdaniem: „Widzisz tu jakiegoś chłopca?" (James 2016: 189), Doktor Love orientuje się, że ma do czynienia z kimś, kto zna hiszpański. Następuje wymiana zdań, która jest najdłuższym fragmentem $z$ użyciem hiszpańskiego:

Doktor Love:

„- Ha, mój błąd. Pero todo es un error en este país de mierda.

- Ale nie tak źle, jak w tym gównianym kraju, z którego przyjechałeś.

- ¿Por Dios, hablas español?

Kiwam głową.

- Hombre z CIA wie?

Kręce głową.

- Chcesz coś wiedzieć? Zachowuj się, jakbyś był głuchy, jakbyś był głuchy jak pień.

- ¿Louis, por qué me has sacado de mi propio jodido país para hablar mierda con ese hijo de puta? 
- Luis, Luis, nada más enséñale al negrito de mierda alguna bobería como una carta bomba. O préstale el libro de cocina del anarquista, qué sé yo. Él y sus muchachos son unos comemierdas, pero son útiles. Por lo menos por ahora." (James 2016: 189-190).

Chociaż czytelnik najprawdopodobniej nie rozumie całego dialogu, ma dowód, że Josey rzeczywiście posługuje się hiszpańskim dość swobodnie. Język Doktora Love wzbogaca treść poznawczą utworu i wzmacnia reakcję emocjonalną czytelnika.

Najprawdopodobniej w opinii anglojęzycznego odbiorcy tekstu prymarnego zdania hiszpańskie służą jedynie zaznaczeniu kulturowej obcości i uwiarygodnieniu narracji. Natomiast czytelnik posługujący się również hiszpańskim, dodatkowo rozpoznaje jego odmianę i rejestr społeczny. Zarówno Doktor Love jak też Josey Wales, w zamiarze autora, posługują się odmianą hiszpańskiego charakterystyczną dla Kubańczyków. W końcowej części książki zawierającej podziękowania czytamy: „Podziękowania kieruję także do Marthy Dicton, która przetłumaczyła fragment na kubański hiszpański, gdy sądziłem błędnie, że meksykański hiszpański załatwi sprawę" (James 2016: 744). Użyte przez polskiego tłumacza słowo "fragment” w miejsce angielskiego "loose English" (James 2015: 688) dość niefortunnie sugeruje, że uwaga dotyczy jakiejś ściśle określonej zamkniętej części powieści a nie wyrażeń pojawiających się w wielu miejscach. Co jednak ważniejsze, zacytowane zdanie sugeruje, że kubańska odmiana języka hiszpańskiego różni się od meksykańskiej. Nasuwa się zatem pytanie, czy czytelnik jest w stanie wychwycić takie niuanse, zasugerowane na poziomie dialogu tylko $w$ jednej scenie, kiedy to Josey stwierdza ze złością: „,a ja marnuje czas (...) bo musze zadzwonić za granice tylko po to, żeby posłuchać, jak Doktor Love i jakiś kretyn przeklinają po hiszpańsku, ale to nie hiszpański z Kuby, więc prawie nic nie rozumiem" (James 2016: 442).

Zapytani o opinię rodowici Hiszpanie, zarówno Prof. Jose Maria Perez Fernandez jak i Dr Maite Escudero Alias, określają zaprezentowane powyżej cytaty jako południowoamerykańską wersję języka. Dr Maite Escudero $^{4} \mathrm{z}$ Uniwersytetu $\mathrm{w}$ Saragossie pisze w prywatnej korespon-

4 Maite Escudero Alias, Dep. Filologia Inglesa y Alemana, Facultad de Filosofia y Letras, Universidad de Zaragoza: Cytowana opinia została wyrażona w korespondencji prywatnej z dnia 21 marca 2016, zgoda na wykorzystanie cytatu wyrażona w e-mailu z dnia 25 kwietnia 2017. Tłumaczenia $\mathrm{z}$ angielskiego dokonały autorki artykułu. 
dencji: „Nie jest oczywistym, że to odmiana kubańska. Na pewno występuje na terenie Ameryki Południowej. My (= europejscy Hiszpanie) nigdy nie użylibyśmy połączenia little putito (little fagot / mały pedałek), ani negrito de mierda (fucker little nigger). Zdrobnienia tego rodzaju (podwójne zdrobnienia, w których oprócz zdrobniałego rzeczownika użyto zdrobniającego przymiotnika) często używane są przez rozmówców z Ameryki Południowej. Jeśli bohater powieści jest Kubańczykiem, możemy się zgodzić, że jest to kubański hiszpański, ale z pewnością ten typ języka występuje nie tylko na Kubie." (prywatny e-mail).

Podsumowując, wykorzystanie języka hiszpańskiego jako elementu narracji służy w powieści ściśle określonym celom. Wśród wielu możliwych funkcji (nazwy funkcji za: Hejwowski 2012: 16), do najistotniejszych należą tu: funkcja treściowa, w której użycie hiszpańskiego służy charakteryzowaniu niektórych postaci świata przedstawionego i dzięki temu wpływa na konstruowanie sensu i treści utworu; funkcja socjologiczna (wskazująca przynależność społeczną i środowiskową bohaterów); funkcja aluzyjna (polegająca na sugerowaniu powiązań politycznych agentów CIA); oraz funkcja kreatywna, która służy pobudzeniu wyobraźni i inteligencji odbiorcy. Polifonia powieści Jamesa uwypukla kontekst społeczno-kulturowy utworu, eksponując stylistyczne nacechowanie języka jako „indywidualne piętno mowy własnej” (Borkowska 1998: 206). Jest też sposobem aktywizacji wiedzy pozatekstowej odbiorcy, zachęcając go do rozszyfrowania inności i obcości. Różnorodność językowa Krótkiej historii, z jej bogactwem dialektów, socjolektów i rejestrów społecznych, stanowi istotny wyznacznik i atrybut świata przedstawionego, ukazując bohaterów w konkretnym czasie i miejscu i ilustrując ich pozycję, status, wykształcenie, pochodzenie, osobowość i cały układ wzajemnych powiązań. Wykorzystanie języka hiszpańskiego jako elementu narracji wzmacnia zatem poznawczo-informacyjny aspekt utworu, wzbogacając naszą wiedzę o świecie i kulturze. Dzieło literackie, wraz z jego fikcyjnym światem przedstawionym, jak przekonują nas liczni badacze i krytycy (Markiewicz 1996: 183, Głowiński 1997: 24-31, Legeżyńska 1984) pełni także funkcję poznawczą, a zatem jego wymiar pozatekstowy zasługuje na szczególną uwagę.

Prozę Jamesa dodatkowo charakteryzują takie „zjawiska sprzyjające polifoniczności" (Korwin-Piotrowska 2011: 106) jak: silnie zaakcentowana intertekstualność i intersemiotyczność z bogactwem odnośników do kultury popularnej, świata muzyki i filmu oraz tekstów biblijnych, operowa- 
nie zmodyfikowaną interpunkcją i zastosowanie zapisu niektórych fragmentów narracji w postaci potoku składniowego. W perspektywie pozaliterackiej, wykorzystanie języka hiszpańskiego w Krótkiej historii siedmiu zabójstw umocowuje dzieło Jamesa w tradycji związku Karaibów z kulturą europejską, nie tylko anglosaską. $W$ historię wyspy silnie wpisane jest piętno kolonizacji - zarówno obecność Brytyjczyków jak i Hiszpanów. Odkryta przez Kolumba Jamajka stanowiła odległy przyczółek władzy hiszpańskiej przez ponad 150 lat (Hauser, Delle i Armstrong 2011: 3). Przypominają o tym do dziś istniejące niektóre nazwy geograficzne, takie jak: Spanish Town, Port Antonio, Montego Bay, czy Columbus Park. W opinii Guillerminy De Ferrari (2007: 12-16), od lat istniejąca kulturowa heterogeniczność Karaibów uczyniła z nich strefę transkulturową, co powoduje, że tradycyjne podziały ulegają zatarciu. Trudno jest wyodrębnić wyobrażoną granicę między Wschodem i Zachodem, czasem przedkolonialnym, kolonialnym i postkolonialnym, elementami dziedzictwa europejskiego i afrykańskiego, czy też hiszpańsko-francusko- bądź anglojęzycznymi obszarami doświadczenia. Powieść Marlona Jamesa przywołuje historyczne uwarunkowania i ukazuje czytelnikom nieustający kontakt i brzemienne w skutki przenikanie się języków, kultur i światów. $\mathrm{Z}$ jednej strony wpisuje się $\mathrm{w}$ nowy rodzaj twórczości autorów pochodzących z Antyli, którzy zachowując lokalny koloryt dotykają problematyki ogólnoludzkiej (D’haen 2014: 28). Z drugiej strony, porusza wyobraźnię nakazując baczniejszą uwagę w stronę większej całości. Sugeruje, że próby zrozumienia kultury regionu muszą prowadzić do odrzucenia podziałów językowych wytworzonych przez czasy kolonialne i rozpoznania specyfiki wzajemnych wpływów, unikalności doświadczenia nazwanego przez Glorię Anzaldúa (1987) „pograniczem kultur.”

\section{BIBLIOGRAFIA}

Anzaldúa, Gloria. 1987. Bordelands. La Frontera: The New Mestiza. San Francisco: aunt lute.

Bachtin, Michał. 1986. Estetyka twórczości słownej, tłum. Danuta Ulicka. Warszawa: Państwowy Instytut Wydawniczy.

Blake, Barry J. 2010. Secret Language: Codes, Tricks, Spies, Thieves, and Symbols. Oxford: OUP.

Borkowska, Grażyna. 1998. „Dialog jako kategoria poetyki” [w:] Henryk Markiewicz (red.), Problemy teorii literatury, Wrocław: Ossolineum, 205-245. 
Cobley, Paul. 2014. Narrative. London and New York: Routledge.

De Ferrari, Guillermina. Vulnerable States: Bodies of Memory in Contemporary Caribbean Fiction. Charlottesville and London: University of Virginia Press.

D'haen, Theo. 2014. „Going Caribbean, Going Global” [w:] Van Haesendonck, Kristian i Theo D'haen (eds), Caribbeing. Comparing Caribbean Literatures and Cultures. Amsterdam and New York: Rodopi, 23-40.

Fägersten, Kristy Beers. 2012. Who's Swearing Now? The Social Aspects of Conversational Swearing. Newcastle upon Tyne: Cambridge Scholars Publishing.

Głowiński, M. 1997. Narracje literackie i nieliterackie. Kraków: Universitas.

Hauser, Mark W., James A. Delle and Douglas V. Armstrong. 2011. „Introduction: Historical Archeology in Jamaica," [w:] Delle, James A., Mark W. Hauser and Douglas V. Armstrong (eds), Out of Many, One People: The Historical Archeology of Colonial Jamaica. Tuscaloosa: University of Alabama Press, 1-20.

Hejwowski, Krzysztof. 2010. „O tłumaczeniu aluzji językowych” [w:] Lewicki, Roman (red.), Przekład - język - kultura, tom II, Lublin: Wydawnictwo UMCS, 41-56.

Hejwowski, Krzysztof. 2012. „Nazwy własne w tekstach literackich - techniki tłumaczenia" [w:] Lewicki, Roman (red.), Przekład - język - kultura, vol. III. Lublin: Wyd. UMCS, 11-12.

James, Marlon. 2015. A Brief History of Seven Killings. London: Oneworld.

James, Marlon. 2016. Krótka historia siedmiu zabójstw, tłum. Robert Sudół. Kraków: Wydawnictwo Literackie.

Korwin-Piotrowska, Dorota. 2011. Poetyka - przewodnik po świecie tekstów. Kraków: Wydawnictwo Uniwersytetu Jagiellońskiego.

Legeżyńska, Anna. 1984. „Architektura świata przedstawionego w przekładzie” [w:] Balcerzan, Edward (red.), Wielojęzyczność literatury i problemy przekładu artystycznego. Wrocław: Zakład Narodowy im. Ossolińskich. Wydawnictwo PAN, 185-206.

Markiewicz, Henryk. 1996. Wymiary dzieła literackiego. Kraków: Universitas.

Riemer, Andrew. 2015. „Bob Marley and the violence in Jamaica - A Brief History of Seven Killings one of Marlon James' little jokes", Sydney Morning Herald, 7 Feb. http://www.smh.com.au/entertainment/books/bob-marley-and-the -violence-in-jamaica--a-brief-history-of-seven-killings-one-of-marlon-jameslittle-jokes-20150131-131yt4.html

Schillinger, Liesel. 2014. "A Brief History of Seven Killings reads like a reggae version of "The Sound and the Fury"'. Christian Science Monitor. http://www. csmonitor.com/Books/Book-Reviews/2014/1009/A-Brief-History-of-Seven -Killings-reads-like-a-reggae-version-of-The-Sound-and-the-Fury

Sparrow, Jeff. 2015. "If it no go so, it go near so" Sydney Review of Books, 3 March. http://www.sydneyreviewofbooks.com/marlon-james-brief-history-sevenkillings/ 
Tayler, Christopher. 2015. „Goings-on in the Tivoli Gardens”. London Review of Books, 37 (21): 45-47.

Wierzbicka, Anna. 1997. Understanding Cultures Through Their Keywords: English, Russian, Polish, German, and Japanese. New York: OUP.

\title{
THE USE OF SPANISH AS A NARRATIVE TECHNIQUE IN MARLON JAMES'S \\ A BRIEF HISTORY OF SEVEN KILLINGS
}

\begin{abstract}
Summary
The article investigates various functions played by Marlon James's use of Spanish in his English language novel A Brief History of Seven Killings (2014). Four overlapping areas of discourse are analysed. The findings suggest that the main functions of the use of Spanish by James's characters are: pointing to the historical presence of CIA agents in Jamaica and Latin America (contentcreating and alluding function), reflecting on Cuban influence in Florida and several Caribbean Island (alluding function), accurate depiction of trade contacts and dealings between Colombian cartels and American gangsters (sociological function), and also an indirect form of characterisation of both Josey Wales, the novel's Jamaican protagonist, and Cuban terrorist Doctor Love (characterbuilding and sociological function). Additionally, the presence of Spanish lexis exposes stylistic markers of an individual's speech, adding to the novel's polyphonic dimension.
\end{abstract}

Key words: Marlon James, A Brief History of Seven Killngs, Jamaica, Cuban Spanish, polyphonic novel

\section{USO DE ESPAÑOL COMO UNA TÉCNICA NARRATIVA EN BREVE HISTÓRIA DE SIETE ASESINATOS DE MARLON JAMES}

\section{Resumen}

El artículo examina diversas funciones de uso de español en la novela de Marlon Jones Breve história de siete asesinatos (2014). Están analizadas quatro áreas coincidentes del discurso. Las funciones más importantes del uso de español por los personajes de Marlon Jones son las siguientes: indicar la presencia histórica de los agentes de CIA en Jamaica y América Latina (para crear contenido y referencias), reflexionar sobre la influencia cubana en Florida y las Antillas (crear referencias), representar con exactitud los contactos comerciales entre los cárteles colombianos y los gángsters americanos (función sociológica), y, finalmente, una manera indirecta de caracterizar a Josey Wales, el protagonista de 
Jamaica, y también al terrorista cubano Doctor Love (función sociológica y de crear del personaje). Además, presencia de léxico español es el señal estilistico de la habla de los individuos y enriquece la dimensión polifónica de la novela.

Palabras clave: Marlon James, Breve história de siete asesinatos, Jamaica, español cubano, novela polifónica

\section{JĘZYK HISZPAŃSKI JAKO ELEMENT NARRACJI W POWIEŚCI MARLONA JAMESA KRÓTKA HISTORIA SIEDMIU ZABÓJSTW}

\section{Streszczenie}

Autorki artykułu analizują funkcje wtrąceń z języka hiszpańskiego w anglojęzycznej powieści Krótka historia siedmiu zabójstw (2015) autorstwa jamajskiego pisarza Marlona Jamesa. Zasadniczą dyskusję poprzedza część informacyjna, zarysowująca konstrukcję utworu, przebieg akcji, sylwetki bohaterów i kontekst społeczno-polityczny przedstawionych wydarzeń. Z punktu widzenia postaci wplatających zwroty i słowa hiszpańskie, odnotowane są cztery zazębiające się obszary dyskursu, które służą określonym funkcjom. Do najistotniejszych należą tu: funkcja treściowa, w której użycie hiszpańskiego służy charakteryzowaniu niektórych bohaterów świata przedstawionego, funkcja aluzyjna (polegająca na sugerowaniu powiązań politycznych agentów CIA działających na terenie Jamajki) oraz funkcja kreatywna, której celem jest pobudzenie wyobraźni czytelnika. Polifonia powieści Jamesa wraz z jej południowoamerykańską wersją języka hiszpańskiego uwypukla kontekst społeczno-kulturowy utworu, eksponując stylistyczne nacechowanie mowy, stając się jednocześnie sposobem aktywizacji wiedzy pozatekstowej odbiorcy i zachęcenia go do rozszyfrowania inności i obcości.

Słowa kluczowe: Marlon James, Krótka historia siedmiu zabójstw, Jamajka, kubański hiszpański, powieść polifoniczna 